\title{
Assessing the Need of Islamic Economics Curriculum in the Nigerian Universities: The Case of Bayero University, Kano
}

\section{Aliyu Dahiru Muhammad ${ }^{1}$, Muhammad Ibrahim Abdullahi ${ }^{1}$}

\begin{abstract}
The persistent deterioration of trust among managers of the economy on one hand, and the declining confidence level of the public on economic and financial institutions in the country calls for the need to assess the type of economic graduates universities in Nigeria produce. In other words, do our universities produce economists that are skillful in the industry but lack ethical as well as moral values? To answer these questions there is a need to examine the university curriculum so as to know the existence or otherwise of courses that enhance skills and those that enhance values. The objective of this study, therefore, is to assess the need for an Islamic economics curriculum that caters not only to building graduate economic and analytical skills but also to the ethical development of a graduate. While Bayero University Kano is not an Islamic University per se, it is well rooted in the values of Islam historically and in the programmes it offers to students from various fields of Islamic revealed knowledge. The paper is based on data from both primary and secondary sources. The primary data were gathered from a survey of both academic staff and students of the Department of Economics, B.U.K. The secondary data were sourced from books, contemporary articles, conference proceedings, reports and curriculum of the department as well as Islamic economics curricula from relevant Universities in the Muslim world. Based on logistic Regression, the findings from this study show that there is a need for Islamic economics
\end{abstract}

${ }^{1}$ International Institute of Islamic Banking and Finance, Bayero University Kano, Email: admuhammad.iiibfbuk@buk.edu.ng 
curriculum to improve the ethical and moral stand of the students, especially after graduation. There is a need for updating the economics curriculum for the Bachelor of Science Economics at Bayero University Kano.

Keywords: Curriculum Assessment; Islamic Economics Curriculum; Nigerian Universities; Bayero University, Kano; Graduates' Quality

\section{Introduction}

The curricula of Nigerian Universities suffer from the setbacks of being static and a times obsolete; not incorporating the dynamism and changes taking place in the nation peoples' lives. For instance, the recent global economic and financial turmoil (2007-2009) has taught us lessons whereby the crisis was, as a result of human greed. The unethical practices of the bankers and financial brokers in the United States who issued sub-prime loans (loans to customers that are not credit worthy), with the aim of maximizing returns through unhealthy competition, not only led to the global financial crisis but also led to structural changes. This has necessitated reviewing social sciences curricula taught to students that will emerge as future bankers in the developed countries. The recent introduction of compulsory entrepreneurship courses for all undergraduate students in Nigerian universities in general and in Bayero University (BUK) in particular is aimed at empowering them to be self-reliant, not always focusing on blue-chip companies or lucrative public offices that may end up being less productive. At the global level, Lewis (2007) describes in his book "Excellence without Soul" the failure of leading universities when it comes to ethics and morality. He writes "The great universities are respected and certainly prized in America, but the public regards with increasing skepticism the values they represent and their failure sometimes to represent any values at all." Recently, Islamic Universities that emphasize ethical values have become more appealing to the public.

Without doubt, the rise in the number of institutions offering Islamic Economics and Islamic banking and finance, including BUK, in based in the relevance and growing faith in role Islamic principles and values play in the 
economic and financial matters today. Interestingly, this development cuts across both Muslim and non-Muslim communities. To Muslims, the development could be understood as Muslims seeking 'own solutions to own problems', but what inspired non-Muslim communities to undertake similar courses is the need to understand the principles governing Islamic economic system which has proved to be resilient to major financial shocks (Abdullahi, 2013).

Bayero University offers Islamic Banking and Finance at postgraduate level through International Institute of Islamic Banking and Finance. However, the Islamic economics component offered at the undergraduate level by the Department of Economics is grossly insufficient. It only includes a few topics in conventional economics focusing on Islamic perspectives and /or an elective course for the students to choose. Thus, the department should be proactive in accommodating the need of the time. The problem is even more obvious because of two facts: firstly, that BUK is situated in a majority Muslim part of Nigeria, and secondly, Islamic economics has arguably received more attention composed to other disciplines in the Islamization of Knowledge (IOK) agenda (Barom and Yusop, 2013). Hence, it seems to be imperative for the department to exert efforts in this direction of incorporating more courses and contents related to Islamic economics. This study therefore, examines the extent of need for Islamic Economics curriculum in BUK and how that will impact on the ethical conduct of the students after graduation.

Accordingly, the paper is expected to be beneficial to the IOK agenda spearheaded by the International Institute of Islamic Thought (IIIT) in Nigeria generally, the department of Economics at BUK and other Nigerian universities sharing similar characteristics. Incidentally, this paper may consequently be beneficial to the entire Nigerian economic and financial environment as it may pave the way for producing graduates instilled with ethical values that will help to cleanse both the public and private sectors from greed and financial recklessness, and to instill financial discipline.

Subsequently, the paper is composed of five sections. It starts with a background, followed by section two which reviews the curricula of Bachelor of Economics degrees offered by Nigerian universities with special reference to BUK. Section three reviews the experiences of selected universities globally which are considered advanced in Islamic Economics. The fourth section 
presents the methodology used in the assessment of need for Islamic economics curriculum in BUK; and section five presents the findings, draws conclusion and proffers recommendations.

\section{BSc. Economics Curricula at Nigerian Universities with specific reference to BUK}

The conventional curriculum for teaching the discipline of Economics in Nigerian universities is contained in the Benchmark Minimum Academic Standards (BMAS). The document serves as a guideline for the minimum academic requirement university students are expected to fulfill for the award of the degree in view. BMAS is a product of Nigeria's National University Commission (NUC) which is empowered by Decree (Act) Number 16 of 1985 and Number 48 of 1988 (as amended) to set minimum academic standards for both undergraduate and postgraduate programmes taught in Nigerian universities. Initially, Minimum Academic Standards (MAS) was developed by the commission for all programmes in 1989. Subsequently, MAS was reviewed after more than a decade and metamorphosed into what is now called BMAS. The review, according to NUC, was necessary to incorporate new developments in the quest of knowledge such as information technology, and to introduce some value-loaded courses such as conflict resolution (NUC, 2007).

Undoubtedly, economics as a discipline forms part of social science because the subject matter is the behavior of 'man' towards material wellbeing. For this reason, the NUC placed the economics curriculum among other social science subjects. Interestingly, BMAS states that the mission of teaching economics in particular and other social science subjects in general is "to produce graduates imbued with the ability to understand and make contributions to the development of Nigeria and the global community" (NUC, 2007). More so, BMAS is specific in its philosophical basis for offering economics as a subject as to "prepare them (the students) to meet the human resource needs for a developing society and develop in them entrepreneurial knowledge, a sense of public responsibility, and a spirit of self reliance" (NUC, 2007). Indeed, this is inspiring because of the strong pronouncement of 'sense of public responsibility'. 
There is no doubt that public responsibility can only be discharged when one understands the nature and causes of societal problems and subsequently devices means. for solving the perceived problems. Yet, there is no qualm that societal norms are value-loaded. What is perceived to be accepted in one society may be unaccepted in another. Hence, Nigerian universities in general, and students in particular, need a thorough understanding and careful analysis of their respective immediate environments, thereby identifying a holistic approach of meeting their social responsibilities in a way deemed acceptable by their communities. Surprisingly, student evaluation criteria, as specified in the BMAS, do not incorporate ethical issues. Rather, they lay emphasis on semester examinations and periodic continuous assessment on the theories taught in class. Accordingly, this may be considered as a great setback to the curriculum especially in attempting to prepare graduates to take societal responsibilities.

With reference to economics, when we examine the break-down of courses students are expected to learn, we discover that There are no courses which directly study the immediate community's problems. For instance, there is no course dealing with the specific beliefs or cultures of varying communities in Nigeria. When one reads through the content of a course titled 'Comparative Economic System' in the BMAS, only systems alien to Nigeria are specified and none of the economic systems which reflect Nigerian values and beliefs are captured. Apparently, considering the number of Muslims in Nigeria, Islamic economics/economic system ought to have been incorporated. Unfortunately, it is not.

Bayero University, Kano (BUK), which is situated in Kano, a predominantly Muslim city, perhaps recognizes the perceived the shortcoming of BMAS, hence incorporating courses with Islamic values in various disciplines, Economics included. However, it is only recently (specifically in the 2013/2014 session) that the department of economics incorporated a specific course 'Islamic Economics' as an elective for level 400 students. Although, this is a welcome development which attempts to instill Islamic values into the system, considering the graduation requirements for B.Sc Economics and the vast nature of Islamic Economics itself, only one 'elective' course is grossly insufficient. For easy comprehension, the breakdown of courses offered by the department across levels of study is summarized in Table 1 below. 
Table 1: Courses offered by the Department of Economics, BUK.

\begin{tabular}{cccccc}
\hline $\begin{array}{c}\text { Level of } \\
\text { Study }\end{array}$ & $\begin{array}{c}\text { Credit } \\
\text { Offered by } \\
\text { the }\end{array}$ & \multicolumn{2}{c}{$\begin{array}{c}\text { Core Courses } \\
\text { Credit }\end{array}$} & \multicolumn{2}{c}{$\begin{array}{c}\text { Elective Courses } \\
\text { Credit }\end{array}$} \\
\cline { 3 - 6 } & $\begin{array}{c}\text { \%Convent } \\
\text { Department }\end{array}$ & $\begin{array}{c}\text { \% Isla } \\
\text { ional }\end{array}$ & $\begin{array}{c}\text { \% Conve } \\
\text { mic }\end{array}$ & $\begin{array}{c}\text { ntional } \\
\text { mic }\end{array}$ \\
100 & 16 & 100 & 0 & 0 & 0 \\
200 & 26 & 46.15 & 0 & 53.85 & 0 \\
300 & 32 & 68.75 & 0 & 31.25 & 0 \\
400 & $32 *$ & 62.5 & 0 & 31.25 & 6.25 \\
\hline
\end{tabular}

*In addition, students are required to register for a 6 credits research paper to be written in the area of their interest which may be Islamic or otherwise. Source: Unpublished document of the Department of Economics, BUK.

Table 1 reveals the gross insufficiency of the Islamic economics component in the department. Out of the total 106 credits offered by the department, only 2 credits (which represent barely 1.89 percent) represent the Islamic economic component. Since the department requires the students to pass minimum of 132 credits before they graduate, they can only select the remaining credit hours from other departments in the Faculty of Social and Management Sciences.

\section{Curriculum of Bachelor Degree in (Islamic) Economics: Global Experience}

As mentioned earlier in the background, Islamic Economics has received the most attention in the IoK agenda. This is due to the problems (mainly economic problems and intellectual crises) which Muslim countries, especially in the Middle-east and Southeast Asia, found themselves facing a few decades after their independence. Hassan (2013) noted that the dominance of the secularist and materialistic western culture, systems and civilization over the Muslim countries and societies in the mid of the $20^{\text {th }}$ Century led to massive and broad range secularization and westernization of Muslim mind, culture, education, politics, economics and law. These perceived problems led Muslim scholars to the search for lasting solutions within the context of Islamic belief. The results were a series of meetings and consultations, till 1977 when the First Conference on Islamic Economics was held in Mecca. The outcomes of the conference were emergence of Universities and other learning and research institutions with a 
tilting interest towards IoK; establishment of many Islamic financial institutions in both Muslims and non-Muslim countries, especially Islamic banks; emergence of experts in Islamic economics and finance; and inclusion of Islamic economics components in many universities including those in the so called 'secular nations' like Nigeria.

Today, many universities around the globe offer Bachelor Degree programmes in Economics with full or partial specialization in Islamic Economics. Thus, the ratio of Islamic contents in their curricula varies across the Universities, depending on their respective graduating requirements. Below the experiences of two different universities are discussed, namely: International Islamic University Malaysia (IIUM) and Agriculture Institute Bogor, Indonesia (IPB).

\section{The experience of IIUM}

The Department of Economics in IIUM forms part of the Kulliyyah (Faculty) of Economics and Management Sciences (KENMS), which was established way back in 1983. The objective of teaching economics in the university is categorically stated by Haneef (2013) as "to produce graduates who are competent in Economics and concomitantly blended with Islamic vision and character so that they can play a meaningful role in the society in which they live". To meet this objective, and unlike what is found in BUK, the department requires undergraduate students to pass through a significant number of courses which are directly or indirectly linked with Islamic economics. In addition, students are also required to take other purely Islamic courses which give them a solid background to the understanding of jurisprudence and shari'ah issues to meet the objective of teaching the subject. For the purpose of comparison, the graduating requirements of the department as at 2010 are summarizes in Table 2.

A quick glance at table 2 reveals how far apart economics graduating requirements of BUK are from those of IIUM. One can vividly see that about 76.6 percent of the credit hours offered to undergraduate economic students have Islamic contents of varying degree, unlike BUK where only a mere 1.89 percent of the total credit hours is Islamic. This further suggests the need to exert more effort in the integration process by the department of economics in BUK. 
Table 2: Bachelor of Economics Graduating Requirement, IIUM

\begin{tabular}{|c|c|c|}
\hline Component & Total credit hours & $\%$ of total \\
\hline Conventional courses $(0 \%)$ & 30 & 23.4 \\
\hline Minor Islamic (1-20\%) & 15 & 11.7 \\
\hline $\begin{array}{l}\text { Moderate Islamic } \\
40 \%)\end{array}$ & 15 & 11.7 \\
\hline $\begin{array}{l}\text { Comparative courses (41- } \\
70 \%)\end{array}$ & 9 & 7 \\
\hline $\begin{array}{l}\text { Complete Islamic } \\
100 \%)\end{array}$ & 18 & 14.1 \\
\hline Fiqh/Usul Fiqh & 18 & 14.1 \\
\hline Other Islamic Courses & 12 & 9.3 \\
\hline Other Discipline & 11 & 8.6 \\
\hline Total & 128 & 100 \\
\hline
\end{tabular}

Source: Adopted from Hannef (2013)

It is imperative to state clearly here that the inclusion of Islamic contents in teaching the discipline of economics does not jeopardize the performance of graduates in the labour market. On the contrary, it enhances their performance as character and productivity are found to be positively correlated by empirical study. Abdullahi, Amin and Haneef (2011) examined the quest for Islamic economics for Universities in the Muslim world. Their work presents a model of an integrated curriculum structure that fulfils the Islamic objectives of higher education while ensuring the various needs of the market are met. The authors also investigated the relationship between the values or character of graduates and work performance. Their findings revealed that there was no conflict between market demands and values. In addition, it was discovered that performance was highly dependent on character. This implied that, apart from technical knowledge taught to students, values were equally, if not more, important to perform well in a career. These findings further buttress the need for inclusion of more ethical courses in BUK curricula, particularly the department of economics. 


\section{The Experience of Agriculture University Bogor, Indonesia}

Teachings of Islamic Economics at Agriculture University Bogor, Indonesia popularly known as Institute Pertanian Bogor (IPB) started way back in 2003 when the first elective course on Islamic economics was offered. Hence, the increasing interest of students to take the course (s) of Islamic Economics prompted the decision of the University in its Faculty Senate Meeting on $25^{\text {th }}$ March, 2009 to offer Bachelor of Islamic Economics and Management to students. In addition, IPB approved the program based on the philosophy of integration of Knowledge with the intent to meet the human resource needs of the rapidly growing Islamic banking and finance in the country. A proposal was then submitted to Senate for final approval and the program was officially launched on May, 2010 with the name 'Bachelor of Islamic Economics' (Beik, 2013).

Table 3: Bachelor of Economics Graduating Requirement, IPB

\begin{tabular}{|c|c|c|c|}
\hline Category & Credit Hours & $\begin{array}{l}\text { Percentage of } \\
\text { Requirement }\end{array}$ & Degree \\
\hline $\begin{array}{l}\text { TPB Courses (University } \\
\text { Required) }\end{array}$ & 31 & $21.38 \%$ & \\
\hline $\begin{array}{l}\text { Inter-departmental (faculty } \\
\text { required) Courses }\end{array}$ & 24 & $16.55 \%$ & \\
\hline $\begin{array}{l}\text { Islamic Turath (heritage) } \\
\text { group }\end{array}$ & 15 & $10.34 \%$ & \\
\hline Islamic Economics Group & $27 \mathrm{C}^{*}+3 \mathrm{E}^{* *}$ & $18.62 \%-20.69 \%$ & \\
\hline $\begin{array}{l}\text { Islamic Management } \\
\text { Banking and Finance Group }\end{array}$ & $17 \mathrm{C}^{*}+3 \mathrm{E}^{* *}$ & $11.72 \%-13.79 \%$ & \\
\hline Other Courses Group & 10 & $6.9 \%$ & \\
\hline Minor Courses & 15 & $10.34 \%$ & \\
\hline Total & 145 & $100 \%$ & \\
\hline
\end{tabular}

Source: Beik, 2013

The curriculum for the program was designed to achieve seven basic competencies as reported by Beik (2013). These include basic agriculture, shari'ah for economics, Islamic Economics, Islamic management, banking and finance, analytical methodology, social, and personal (akhlaq and morality). These competencies are believed to prepare the students for the challenges ahead after graduation particularly on ethical and moral development of the society at large and graduates in particular. 


\section{The Present Study}

This section presents the methodology used in the process of undertaking this research. It reviews the history of the case study (BUK) and the techniques employed in handling the data used, ranging from method of data collection to the method of data analysis.

\section{Overview of Bayero University Kano}

The University started as a college in 1966. Recently, the University has a total population of 29,777 students with over 21,000 undergraduate and over 5,000 postgraduate students. It also has the staff strength of 3,323 out of which 1,223 were academic staff as at 2014 .

In recognition of the values and culture of the people the University is located, the council established IIIBF and Centre for Qur`anic Studies to carry out researchers and programmes pertaining to Islamic banking and finance as well as on problems of the almajiri system of education (informal Quranic Education), respectively. The University is also geared toward integration of courses whereby a graduate of Arabic would be computer literate through a number of computer courses he might be required to register in his/her programme. The University gives freedom to various faculties and departments to incorporate courses they deem fit in advancing their disciplines and in promoting multi-disciplinary approach to research and teaching. According to the Vice Chancellor, Prof. Abubakar A. Rasheed at the University congregation on $6^{\text {th }}$ May, 2015, it is the responsibility of any department to propose or introduce courses that would link its department with another departments or faculties. He added that, any department that desired integration should make alliance with course outside the department or even faculty as the integration is usually initiated from bottom to the top. However, this enormous task must be carried out carefully so as not to compromise with the respective specializations that promotes efficiency, quality assurance and competitiveness. The BUK's main goal is to deepen the quality of knowledge of its graduates. In fact, for a more meaningful and comprehensive integration, the philosophy of the curriculum must be modified. 


\section{Type and Source of Data}

The research work relies heavily on primary data which was sourced from selected respondents. In other words, field work of data collection is the technique employed by the researchers. This is in an attempt to gather original information to be used in undertaking this work. However, secondary data is not totally neglected as it gives information on the current status of the department under investigation. So documents from the department and the university were thoroughly investigated.

\section{Population and sample}

The population of this study consists of members of academic staff and students of the department of Economics, BUK. This includes both B.Sc Economics and B.Sc Banking and Finance students, both of which are offered by the department. Currently, the department has 34 academic staff and over 1000 students.

The study, using purposive sampling technique reaches out to 50 samples from the population. Purposive sampling is a non-probability sampling technique and as the name implies the sample is drawn purposively to achieve a particular goal (Anderson, Sweeny and Williams, 2002). Thus, students`volunteers/leaders from the department of Economics were used to distribute 50 copies of the survey questionnaire to their colleagues and the remaining 10 copies were administered on the members of academic staff by the researchers.

\section{Instruments of Data Collection}

Questionnaire was the instrument used in obtaining the needed information from targeted respondents. The questionnaire is divided into two (2) sections; first section seeks for the personal information of the respondents whereas questions in the second section are directed towards soliciting respondent's view on the need for Islamic economics curriculum and its role in promoting ethical and moral conducts of graduates of economics in Nigeria with special reference to BUK.

Both descriptive and inferential statistics were used in analyzing the information sourced from respondents. For the descriptive statistics, simple frequencies and percentages were employed and logical analysis made. Meanwhile, the 
inferential statistical method employed is the binary logistic regression. The logistic regression was used primarily to determine such factors influencing respondent's preference towards Islamic or conventional economics and to determine such factors that influence respondents' ethical and moral conducts.

\section{Results and Discussion}

This section presents the findings of this research work. Out of the total 50 copies of the questionnaire distributed to respondents, 47 were successfully completed and returned; all the 47 were found to be valid. The response rate is very impressive as it represents 94 percent of the total number of copies distributed; and this in itself demonstrates the desire that the respondents, both members of staff and students, have interest in this area. Hence, this pioneered work is expected to shed light in exploring this hitherto untouched but important area of research.

Of the 47 respondents 38 are male representing 80.9 percent while the remaining 9 (19.1 percent) are female. Although the rate is not evenly distributed but it represents, to some extent, both gender because even the female 19.1 percent is a fair representation. Meanwhile, the distribution by age is also fair as it reflects true composition of the population. Specifically, 7 (14.9 percent) respondents fall below the age of 20, whereas 30 respondents, representing 63.8 percent constitutes those aged 20-30 years. Again, 8 respondents, representing 17 percent, aged 31-40, and only 2 respondents, equivalent to 4.3 percent aged $41-50$ years.

However, the distribution by religion is skewed as Muslims form the bulk of the respondents of 45 or 95.7 percent of the total response, with only 2 respondents (4.3 percent) as Christians. To some extent we can conclude that this study represents the views of Muslims only which is not a surprise considering the environment. In contrast, the educational levels of the respondents vary considerably across levels with 37 respondents (78.7 percent) as undergraduate students who form the majority. Others include 6 master's degree holders representing 12.8 percent and the remaining 4 respondents ( 8.5 percent) obtained their PhDs. 
The second section asks specific questions on the need for Islamic economic courses in the current economics curriculum and its role in promoting ethics and morality of economists. Firstly, a question was asked whether respondent has taken/taught any course on ethics and morality in the university; interestingly, 30 respondents, representing 63.8 percent, have taken such courses, perhaps at general studies level. However, the other 17 respondents (36.2 percent) have not taken any course in that respect which is indeed a cause for concern.

Next, the respondents were asked whether they would be willing to take/teach Islamic economic courses. Almost all (95.7 percent) of the respondents demonstrated willingness to partake in learning or teaching Islamic economics; unfortunately, the current curriculum denies them that opportunity. The next question was explicit as it asks respondents to specifically indicate their preferences between conventional and Islamic economics. Interestingly, 41 respondents, representing 87.2 percent prefer Islamic economics than its conventional counterpart. This in itself reaffirms the dire need for Islamic economics courses among those specializing in economics. Only 6 respondents (12.8 percent) preferred conventional economics.

Although most of the respondents, 68.1 percent to be specific, believe that the current curriculum of economics promotes ethics and morality and of the view that graduates of economics abide by the ethical and moral principles in work place, however, 85.1 percent of the respondents believe that inclusion of Islamic economics courses can enhance the ethical and moral conducts of the graduates. Hence, this is another emphasis on the need for such courses to be introduced.

\section{Factors Influencing Perceptions toward Islamic Economics}

Using SPSS software version 16.0, the results of the two seprate models are presented below in Table 4 and Table 5.

The first model is designed to study such factors that influence perception of respondents on whether Islamic economics promotes ethics and morality of the graduates, whereas the second model studies such factors that influence preference of respondents towards Islamic economics. Gender, age and educational level are also included in the two models to see if they have any influence. 
Table 4: Likelihood that IE promotes Ethics and Morality (binary logistic regreession)

\begin{tabular}{|c|c|c|c|c|c|}
\hline $\begin{array}{l}\text { Variable } \\
\text { (p-value) }\end{array}$ & $\beta$ (SE) & Wald $^{2}$ & & EX (B) & Sig. \\
\hline Gender & $-2.664 *(1.465)$ & 3.306 & & 0.070 & 0.069 \\
\hline Age & $-0.121(1.309)$ & 0.009 & & 0.886 & 0.926 \\
\hline Education & $-2.708 *(1.617)$ & 2.807 & & 0.067 & 0.094 \\
\hline WTTIE & $21.573(25870)$ & 0.000 & & 2.33E9 & 0.999 \\
\hline PFIE & $3.349 *(1.901)$ & 3.104 & & 28.484 & 0.078 \\
\hline CEPEM -3.9 & $7 *(2.247) \quad 3.166$ & & 0.018 & & \\
\hline Constant -9.3 & 84 (25870) & & 0.000 & & \\
\hline$\underline{\mathrm{n}}=47,-2 \log 1$ & kelihood=23.937, $\mathrm{R}$ & $=0.283(C$ & ox \& S & ell), $0.49^{\prime}$ & kerke), \\
\hline
\end{tabular}

Table 5: Preference for IE over CE (binary logistic regreession)

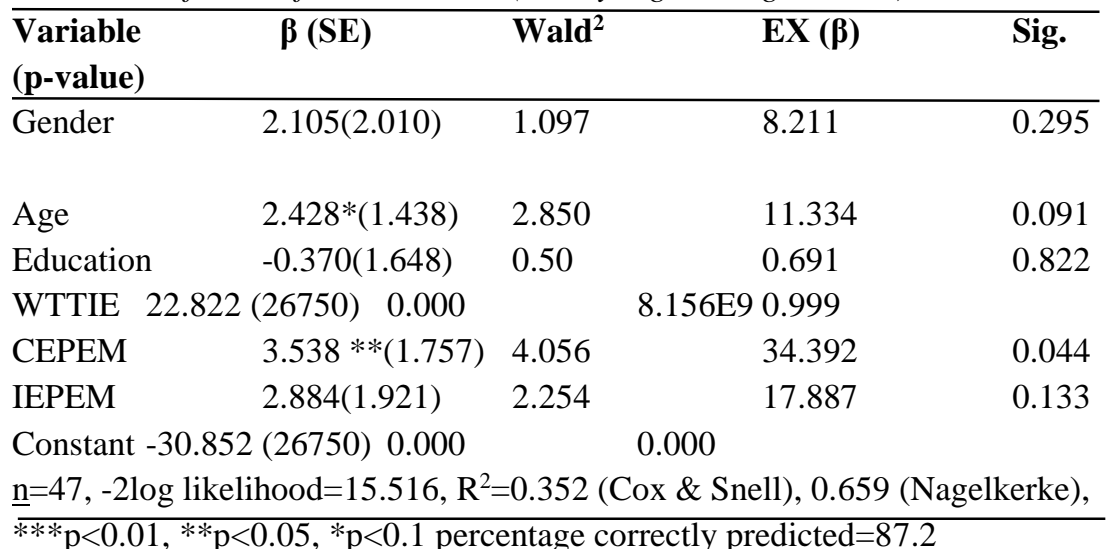
Source: Researchers' computation using SPSS 16.

The results for perception of respondents on whether Islamic economics promotes ethics and morality of the graduates (Table 4) indicate that gender $(p<0.1)$ significantly and negatively affects the perception on whether Islamic economics promotes ethics and morality among respondents, with the odd ratio $(\mathrm{EX} \beta)$ as low as 0.070 , which shows this perception is favored by male respondents than female. Likewise, education $(\mathrm{p}<0.1)$ significantly and 
negatively affect the perception with odd ratio (EX $\beta$ ) equally low as 0.067 , which shows this perception is favored by younger respondents. This finding shows that Islamic economics has a bright future as younger academicians have passion in the area.

Besides gender and education level, respondents that prefer Islamic economics over its conventional counterpart are of the view that the area is capable of promoting ethics and morality of students $(\mathrm{p}<0.1)$ with odd ratio as high as 28.484. In contrast, respondents who have the view that the current (conventional) economics curriculum promotes ethics and morality hold the perception that introducing Islamic economics component may not promotes ethics and morality of the students $(\mathrm{p}<0.1)$. Hence, the odd ratio is as low 0.018 ; in any case this finding seems to be very logical because if respondent is confident that current curriculum suffices then he may not require any change.

The results of the second model on Table 5 indicate that only age of the respondents and their view on whether conventional economics promotes ethics and morality impact on their preferences of Islamic economics over conventional economics curriculum. Age is found to be positively and significantly related to Islamic economics preference $(\mathrm{P}<0.1)$ with high odd ratio of 11.334 , meaning that as respondent gets older his/her preference towards Islamic economics increases. Ironically, the result indicates that respondents who hold the view that conventional economics promotes ethics and morality equally preferred Islamic economics over conventional economics $(p<0.05)$, and the odd ratio is high at 17.887 . However, it seems there is absence of any course on ethics and morality offered by the department. This means that complementing conventional economics with some Islamic contents will significantly promote ethics and morality of the graduates of economics.

\section{Conclusion and Recommendations}

This section concludes the paper based on the results obtained. Subsequently, recommendations are offered based on the conclusion arrived at. This paper examines the extent of the need for Islamic Economics curriculum and how such will impact on the ethical conducts of the students after graduation using department of economics, BUK as a case study. The paper critically reviews the current economics curriculum as being taught in the department in reference to what is found in other Muslims dominated universities in the world. Thereafter, 
data was collected from academic staff and students of the department on the basis of which analysis was conducted.

From the analysis of the data obtained the paper concludes that majority of the respondents show their preferences of Islamic economics curriculum over conventional one, with older members of the department having profound influence on that. Equally, it is concluded from the findings that complementing Islamic economics component into current conventional curriculum will improve the ethics and morality of economic graduates at working place.

Notwithstanding, male respondents that are mostly undergraduate students of economics think that introducing Islamic economics component will significantly improve the ethical and moral conducts of the graduates of economics at working place. Hence, this suggests further the need for Islamic economics components especially at the undergraduate level and leads to the conclusion that Islamic economics curriculum promotes ethics and morality of graduates. In this case, Islamic Economics could be used to promote market disciplines, ethical considerations in business and economic activities and above all promoting societal welfare while pursuing individual rights and obligations.

Based on the above conclusion the following recommendations are offered:

1. There is strong need for introducing more Islamic economics components by the department of Economics, BUK especially at undergraduate level to prepare minds of the future economists on ethical conduct after graduation.

2. There is the need for other Nigerian universities, especially those sharing similar characteristics with BUK, to introduce Islamic economics courses into their programmes.

3. The NUC should embark on curricula evaluation exercise in order to gather information on the dynamic needs and expectations of the respective Nigerian universities/communities. 
4. Although options should be provided to students to choose the area they want to specialized (whether Islamic or otherwise), however, compulsory courses on ethics and morality should be introduced in the department.

5. There is need for increasing collaborations between the IIIBF-BUK and the Department of Economics especially in the area of training and re-training of staff, curriculum development, teaching and research among others.

\section{References}

Abdullah, S. Amin, R. and Haneef, (2011). The Quest for a $21^{\text {st }}$ Century Islamic Economics Curriculum for Universities in the Muslim World: The Case of the IIUM, in Bakar O. Eric, W. and Airulamri, A. (eds). Contemporary Higher Education Needs in Muslim Countries. Kuala Lumpur.

Abdullahi, M. I. (2013): A Theoretical Introduction to Islamic Banking and Finance. In Dandago, K. I., Muhammad, A. D. \& Oseni, U. A. (eds), Essentials of Islamic Banking and Finance in Nigeria, Kano: Benchmark Publishers Limited.

Anderson, D. Sweeny, D. and Williams, T. (2002). Statistics for Business and Economics, Eighth Edition, South-Western, US.

Bakar O. Eric, W. and Airulamri, A. (2011). (eds). Contemporary Higher Education Needs in Muslim Countries. Kuala Lumpur.

Barom, M. and Yusop, M. (2013). Islamic Economics Education in Southeast Asian Universities: An Introduction, in Barom, et al. (eds), Islamic Economics Education in Southeast Asian Universities, Centre for Islamic Economics, IIUM and International Institute of Islamic Thought

Barom, M. Yusop, M. Haneef, M. Mohammed, O. (2013) (eds), Islamic Education in Southeast Asian Universities (edit), Centre for Islamic Economics, IIUM and International Institute of Islamic Thought

Beik, I. (2013). The Development of Islamic Economics Curriculum at Institut Pertanian Bogor (IPB) in Barom, et al. (eds), Islamic Economics 
Education in Southeast Asian Universities, Centre for Islamic Economics, IIUM and International Institute of Islamic Thought

Haneef, M. Amin, R. (2013). Islamic Economics Education in Malaysia: A Comparative Analysis of the Bachelor of Shariah (Shariah and Economics), University of Malaya, and the Bachelor of Economics, International Islamic University Malaysia, in Barom et al. (eds), Islamic Economics Education in Southeast Asian Universities, Centre for Islamic Economics, IIUM and International Institute of Islamic Thought

Haneef, M. (2013). Teaching of Islamic Economics at IIUM: The Challenges of Integration and Islamization, in Barom et al. (eds), Islamic Economics Education in Southeast Asian Universities, Centre for Islamic Economics, IIUM and International Institute of Islamic Thought

Hashim, R. (2013). Higher Education Curriculum Development for Islamization of Knowledge, in Barom, et al. (eds), Islamic Economics Education in Southeast Asian Universities, Centre for Islamic Economics, IIUM and International Institute of Islamic Thought

Hassan, M. K. (2013) Islamization of Human Knowledge in Baron et al. (eds), Islamic Economics Education in Southeast Asian Universities, Centre for Islamic Economics, IIUM and International Institute of Islamic Thought

Rasheed, A. (2015). Presentations on the Updates of Programmes and Projects in the University, $47^{\text {th }}$ Congregation of Bayero University Kano, $6^{\text {th }}$ May, 2015. 